\title{
Influence of Demographic Factors on Job Satisfaction of Financial Institutions Workforce of Nepal
}

\author{
Indira Shrestha ${ }^{1}$
}

\begin{abstract}
This paper examines the influence of demographic factors on job satisfaction of employees of Nepalese Financial Institutions. The survey instrument was distributed to the employee of commercial banks, development banks and finance companies located at Lekhnath municipality and Pokhara Sub-metropolitan city. The sample size for this study was 150. The sample was selected using strati-fied sampling. This study presented communication, career development, and role of employee, working condition, recognition, and reward, immediate supervisor, and training pro-gram as factors of job satisfaction. Data were analyzed by using statistical tools like frequency, mean, and percentage. Moreover to test the hypothesis presented in this study, independent t-test, ANOVA analysis have been used. This research concluded that demographic variables (gender, job position, and age) influence the level of job satisfaction of employees of Nepalese financial institutions.
\end{abstract}

Keywords: Demographic Factors, Job Satisfaction, Nepalese Financial Institutions

\section{Introduction}

Financial institutions of Nepal are playing important role in the overall economic development of country. In Nepal financial institutions have been growing in sufficient number after the declaration of liberal policy related to financial institutions by Nepal Rastra bank. It seems that job satisfaction of employees is the key to productivity of any kinds of organization. The job satisfaction is one of the important issues for management, organizations and researchers (Locke \& Latham, 2000). Job satisfaction is an attitude which shows the level of being happy or unhappy with the workplace, work, and organization. That is satisfied workers have positive perception \& attitude toward their organizations (Rocca, \& Konstanki, 2001; Dessler, 2005). So organizations must know about the variables which satisfy the employees as well as factors which determine the level of job satisfaction of workers in organizations. Thus a leading stream of research in job satisfaction is about the demographic impacts on the employee's attitude because these personal and contextual variables have been found significant in affecting the performance level of any workforce (Sokoya, 2000). The concept on influence of demographic variables on level of job satisfaction is still one of the most challenging and researched concepts in the fields of human resource management, organization behavior. A variety of studies have been conducted to explore, the concept on influence of demographic variables on job satisfaction in many countries besides Nepal. So the objective of this study is to explore demographic variables influencing job satisfaction of financial workforce of Nepal.

\section{Literature Review}

An array of research is going on to explore the job satisfaction of employees of different kinds of organization because which is directly related to contributions of employees to these organizations.

The literature survey reveals that which contribute to the job satisfaction of any worker or officers are:

${ }^{1}$ Lecturer, Tribhuvan University 
pay, work, environment, coworkers (Robbins, 1998) Likewise adequate equipment, required resources, training opportunity and an equitable workload all affect an employee's job satisfaction (Ellickson \& Logsdon, 2001). Ellickson and Logsdon (2001) argued that job satisfaction has two major groups of causes: environmental antecedents (work related factors) and personal factors. The job satisfaction like work, pay, supervision, promotion, co-worker and the demographic features of the employees and organization determine job satisfaction (shah \&Jalees, 2004, Tsigilis et al. 2006)

Daftuar (2001) stated that in terms of personal characteristics affecting job satisfaction, it appears that higher occupational levels are generally associated with higher job satisfaction.

Beisiegel (2003) found that there was no significant gender difference in job satisfaction. He has stated that it is the specifics of the job impact on job satisfaction and not the gender of the employee itself and this is accounted for the absence of a significant direct correlation between job satisfaction and gender.

Katuwal and Randhawa (2007) their study results revealed that the textile workers in Nepal have a high dissatisfaction with the facets of the job that involved the monetary expenditure of the organization, the behavioral aspects of management and the employment policy of the organization

According to Ali, Ewan and Duska (2008) variables such as age, gender, work experience years, organizational position, types of employment and salaries received and benefits were seen as having effects on their job satisfaction.

Cetin (2006) showed that differences in job satisfaction according to gender, marital status and age was not significant.

Orisatoki and Oguntibeju (2010) found that there was no significant satisfaction difference between gender and age groups. There was positive correlation between job satisfaction with understanding the goals and the objectives of the management and sense of belonging. There was no significant correlation of job satisfaction with other factors such as knowledge about workplace, work stress, relationship with colleagues but negative correlation of job satisfaction with salary.

Din, Zaman, \& Nawaz (2010) found that designation, university sector and gender have significant impact on job satisfaction of the academicians in university of North West Frontier Province (NWFP), Pakistan.

In Nepal there are challenges to motivate employees and make them feel that they are safe and secured in jobs. Except few joint venture banks' job in Nepalese organizations are not challenging, interesting and motivating to enhance quality of work life (Adhikari \& Gautam, 2011).

Ranjit (2012) conducted study on influence of demographic factors on job satisfaction of workers of selected mills registered under South Indian Mills Association (SIMA) and his study results revealed that textile mill workers had moderate level of job satisfaction and found that demographic variables like age, marital status, educational qualification, years of experience, monthly income, nature of industry, welfare facilities and working condition do influence the level of job satisfaction of textile mill workers.

Bhati and Ashok Kumar (2013) studied relationship between demographic variables and job satisfaction of employees of Ceramic Industry and found that age, educational qualification, occupation, years of experience, monthly income, hours of work, overtime hours do influence the level of job satisfaction of workers.

Tabatabaci, Ghaneh, Mohaddes and Khansani (2013) found significant differences in job satisfaction of men and women, single and married, formal and contract recruitment samples \& between groups with different salaries . 
Dependent variable

Independent variables

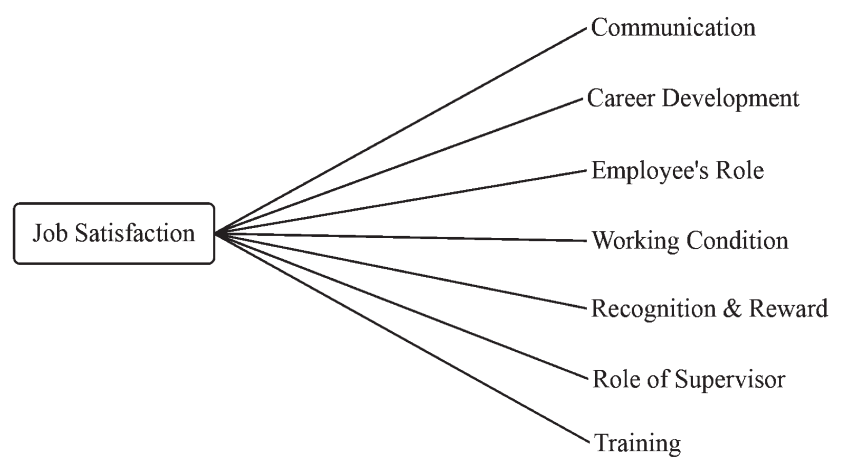

Figure I: Theoretical Framework

Moderating variable (Gender, marital status, job position, service year, education \& age)

\section{Data and Methodology}

This research is mainly based on primary data collected through well framed structured questionnaires to know the opinion of the respondents. The universe for this study is the employees of the selected financial institutions. Financial institutions are stratified into three strata namely commercial banks, development banks, and finance companies. Financial institutions situated at Pokhara Sub-metropolitan city and Lekhnath municipality have been taken as population for this study. To represent the population 200 questionnaires were distributed to respondents but only 150 questionnaires were usable so sample size for this study was 150 . Out of which 62 respondents were from commercial banks, 45 from development banks, and 43 from finance Companies. The researcher has adopted stratified random sampling technique for selecting the sample for the study.

\subsection{Measurement}

Job satisfaction refers to positive or negative feeling towards job. There are many factors which determine job satisfaction of employees. Following is a brief account of the factors of job satisfaction.

Communication: communication is one of the important factor of job satisfaction. Employee's job satisfaction is determined by how organization's policy and procedure are communicated as well as frequency of communication Career development: employees prefer their clearly established career path in their organization and want to learn and grow career so organization should make them clear about their career path which will lead to employee's motivation Employee's role: job satisfaction of employees is based on the types of roles played by employees and degree of decision making authority.

Working condition: working condition of organization is more powerful determinant of both productivity and employee satisfaction. Reasonable load, work life balance, package of holiday are important determinant of good working condition.

Recognition and reward: another most important factor of job satisfaction is recognition and reward Employees will be more satisfied if they are recognized and rewarded for work that is well done and considers them as a valuable resource.

Role of supervisor: supervision is the function of leading, coordinating and guiding employees at their job to accomplish organization's goals so supervisor can play effective role by guiding their job, motivating employees treating employees with respect to increase productivity leading to job satisfaction.

Training program: training program is necessary for employees on the basis of need so initial training and ongoing trainings play vital role for increasing job satisfaction of employees. All the job satisfaction factors were measured on a Likert's 5 points scale ranging from strongly agree (5), agree(4), Neutral(3), disagree(2) and strongly disagree(1). Moderating variables for this questionnaires are gender, marital status, job position, service year, education, and age. Cronbach's Alpha coefficient was tested and found 0.927 .

\subsection{Analysis and Interpretation}

The frequency, percentage, means, ANOVA and independent sample t-test were employed to analyze the results of quantitative method using SPSS.

\subsection{Hypothesis Development}

1. $\mathrm{H}_{0}$ : there is no significant difference in job satisfaction level with respect to marital status, gender, service year, education level and age. 


\section{Empirical Analysis}

Table I: Social-demographic Profiles of Respondents

\begin{tabular}{|c|c|c|c|}
\hline Personality & & $\begin{array}{c}\text { Respon- } \\
\text { dent }\end{array}$ & $\begin{array}{c}\text { Percentage } \\
(\%)\end{array}$ \\
\hline \multirow{3}{*}{ Gender } & Male & 89 & 59.33 \\
\hline & Female & 61 & 40.67 \\
\hline & Total & 150 & 100 \\
\hline \multirow{5}{*}{$\begin{array}{l}\text { Marital } \\
\text { Status }\end{array}$} & Married & 81 & 54 \\
\hline & Single & 69 & 46 \\
\hline & Divorced & 0 & 0 \\
\hline & Widow & 0 & 0 \\
\hline & Total & 150 & 100 \\
\hline \multirow{5}{*}{ Job Position } & Assistant & 92 & 61.33 \\
\hline & Officer & 30 & 20 \\
\hline & Sr. officer & 13 & 8.67 \\
\hline & Manager & 15 & 10 \\
\hline & Total & 150 & 100 \\
\hline \multirow{6}{*}{ Service Year } & Less than one & 12 & 8 \\
\hline & $1-3$ & 69 & 46 \\
\hline & $4-8$ & 56 & 37.33 \\
\hline & $9-15$ & 13 & 8.67 \\
\hline & Over 15 & 0 & 0 \\
\hline & Total & 150 & 100 \\
\hline \multirow{6}{*}{ Education } & +2 Level & 5 & 3.33 \\
\hline & Bachelor & 50 & 33.33 \\
\hline & Masters & 95 & 63.33 \\
\hline & M. Phil & 0 & 0 \\
\hline & Doctorate & 0 & 0 \\
\hline & Total & 150 & 100 \\
\hline \multirow{6}{*}{ Age } & Under 20 & 1 & 0.67 \\
\hline & $20-25$ & 45 & 30 \\
\hline & $26-30$ & 69 & 46 \\
\hline & $31-35$ & 20 & 13.33 \\
\hline & Over 35 & 15 & 10 \\
\hline & Total & 150 & 100 \\
\hline
\end{tabular}

With regard to the number of employees from different Nepalese financial institutions, the result showed that 62 from commercial bank, 45 from development bank, and 43 from financial institutions.

The highest percentage of respondents in Nepalese financial Institutions was male with 59.33 percent as compare to female with 40.67 . With regard to marital status of respondents, the result showed that married respondent with highest percentage at 54 whereas single were at 46 percent.

With regard to job position the result showed that assistant with highest percentage at 61.33 percent as compare to officer with 20 percent, senior officer with 8.67 percent, and manager with 10 percent.

Regarding the year of service of respondents in the organization, most of the respondents were 1-3 years at 46 percent, whereas $4-8$ years at 37.33 percent, 9-15 years at 8.67 percent, less than one year at 8 percent

Regarding the educational level of respondents, result showed that masters with highest percentage at 63.33 percent, whereas bachelor with 33.33 percent, and +2 levels with 3.33 percent.

Regarding the age group of respondents, result showed that respondents were mostly between 26-30 years with 46 percent, 20- 25 years with 30 percent, 31-35 with 13.33 percent, over 35 years with 10 percent and under 20 years with 0.67 percent.

Table II: Demographic Factors and Variables of Job Satisfaction

\begin{tabular}{lccccccc}
\hline \multirow{2}{*}{$\begin{array}{c}\text { Job } \\
\text { Satisfaction }\end{array}$} & $\begin{array}{c}\text { Variables Gender } \\
\text { (p value) }\end{array}$ & $\begin{array}{c}\text { Marital status } \\
\text { (p value) }\end{array}$ & $\begin{array}{c}\text { Job position } \\
\text { (p value) }\end{array}$ & $\begin{array}{c}\text { Service Year } \\
\text { (p value) }\end{array}$ & $\begin{array}{c}\text { Education } \\
\text { (p value) }\end{array}$ & $\begin{array}{c}\text { Age } \\
\text { (p value) }\end{array}$ \\
\hline 1 & Communication & $.079^{*}$ & .539 & $.001^{* * *}$ & $.065^{*}$ & .740 & $.001^{* * *}$ \\
2 & $\begin{array}{c}\text { Career } \\
\text { development }\end{array}$ & .728 & .597 & $.019^{* *}$ & .234 & .660 & $.050^{* *}$ \\
3 & Employee's role & $.008^{*}$ & .803 & $.001^{* * *}$ & .376 & .424 & $.038^{* *}$ \\
4 & Working condition & .306 & .694 & .106 & .892 & .976 & .245 \\
5 & $\begin{array}{c}\text { Recognition and } \\
\text { reward }\end{array}$ & $.027^{* *}$ & .886 & $.002^{* * *}$ & $.084^{*}$ & .863 & $.004^{* * *}$ \\
6 Role of supervisor & .339 & .497 & $.096^{*}$ & .480 & .609 & .112 \\
7 & Training & .236 & .729 & .168 & .317 & .224 & .062 \\
\hline
\end{tabular}

${ }^{*}{ }^{* *}{ }^{* * * *}$ means the statistics is significant at $10 \%, 5 \%$ and $1 \%$ level of significance respectively. 
ANOVA analysis shows that there is significant difference in the career development of employees with respect to job position and age of employees at 0.05 level. But there is no significant difference in the career development with respect to service year and education of employees, marital status and gender.

T-test shows that there is no significant difference in the career development with respect to gender and marital status of employees.

T-test shows that there is significant difference in the role of employees with respect to gender at 0.1 level but no significant difference with respect to marital status of employees. ANOVA analysis shows that there is significant difference in the role of employees with respect to job position and age of employees at 0.001 , and 0.05 level respectively but no significant difference with respect to years of service and education of employees.

T-test and ANOVA analysis show that there is significant difference in working condition with respect to gender, marital status, job position, service year, education, and age of employee.

T-test shows that there is significant difference in recognition of employee and reward system of organization with respect to gender at 0.05 level but no significant difference with respect to marital status of employees. ANOVA analysis shows that there is significant difference in recognition and reward with respect to job position, service year, and age of employee at $0.05,0.1$, and 0.001 level respectively but no significant difference with respect to education of employees.

T-test shows that there is no significant difference in role of supervisor with respect gender and marital status of employee. ANOVA analysis shows that there is significant difference in role of supervisor with respect to job position at 0.1 level but no significant difference with respect to service year, education, and age of employees.

T-test shows that there is no significant difference in training program with respect to gender and marital status of employees. ANOVA analysis shows that there is significant difference in training program with respect to age at 0.1 level but no significant difference with respect to job positon, service year, and education of employees.
Table III revealed that there is significant difference in the level of job satisfaction with respect to male and female employees at 0.05 level. It is evident that gender influences the level of satisfaction of the respondents. So hypothesis set for this research has been rejected. In case of marital status there is no significant difference in the level of job satisfaction with respect to married and unmarried employees. So hypothesis set for marital status has been accepted and this finding is not supported by Ranjit (2012).

The ANOVA value $(\mathrm{F}=5.556)$ shows that there is significance difference in the level of job satisfaction with respect to job position of employees at 0.001 level. It is inferred that higher the position higher is the level of job satisfaction and vice versa. The hypothesis set for job position has been rejected.

The ANOVA analysis showed that there is no significant difference in the level of job satisfaction among the employees with respect to years of service $(p>0.05)$. The finding shows that years of service of employees does not influence the level of job satisfaction. The hypothesis set for service years has been accepted and this finding is not supported by Ranjit (2012).

The ANOVA analysis showed that there is no significant difference in the level of job satisfaction with respect to education level of employees $(p>0.05)$. The hypothesis set for level of education of employees has been accepted and this finding indicates that level of education does not influence the level of job satisfaction of employees. 
However this finding is not supported by Ranjit, (2012) \& Sukumar (2009).

The ANOVA analysis showed that there is significant difference between age of employees and level of job satisfaction at 0.01 level. It is concluded that higher the age higher is the level of job satisfaction. This finding is supported by Ranjit (2012), Tom, \& Smith (2007).

\section{Conclusion}

The result revealed the influence of demographic variable (gender, marital status, job position, service years, education, and age) on job satisfaction of employees of Nepalese financial institutions. Communication, career development, role of employee, working condition, recognition and reward, role of supervisor, and training program have been taken as independent variables. In banking sector in Nepal, gender, job position, service year, age of employees do influence on communication pattern of organizational communication whereas marital status, education do not have any influences. Job position, and age of employees have influence on career development whereas gender, marital status service year, education do not have any influences. Gender, job position, and age of employees have influences but marital status, service year and education do not have any influence. The result revealed that, job position, and age of employees influence the level of job satisfaction in Nepalese financial institutions. This study also reveals that there is no influence of years of service, level of education, and marital status of employees on level of job satisfaction.

\section{References}

Adhikari, D.R, \& Gautam, D.K. (2011). Employees' commitment and organizational performance in Nepal: A typology framework. SEBON Journal, 2, 1-17.

Beisiegel,H., (2003). Diversity builds strength. Productivity, 19(2), 26.

Bhati, P. P., \& Ashok, M. (2013). Study relationship between demographic variables and job satisfaction of employee of ceramic industry. Global Reserch Analysis International, 2(9), 114-116.

Cetin, M. O. (2006). The relationship between Job Satisfaction, Occupation and Organization Commitment. Academy of Business Journal, 8(1), 78-90.

Daftuar, C. N. (2001). Job satisfaction among government officers: A comparison of three $\mathrm{m}$ e a s u r e s . Abhigyan, 19(3), $33-39$.

Din, S.U., Zaman, K.U \& Nawas, A. (2010). Impacts of demographic variables on job satisfaction of the academicians in University of NWFP. Pakistan Bulletin of Education \& Research, 32(1), 53-58.

Ellickson, M., \& Logsdon, K. (2001). Determinants of job satisfaction of municipal government employees. State and Local Government Review, 33(3), 173-84.
Katuwal, S. B., \& Randhawa, G. (2007). A study of job satisfaction of public \& private sector Nepalese textile workers. Indian Journal of Industrial Relations, 43(2), 15-31.

Mosadeghrad, A. M., Ferlie, E., \& Rosenberg, D. (2008). A study of the relationship between job satisfaction, organizational commitment and turnover intention among hospital employees. Health Services Management Research, 21(4), 211-227.

Orisatoki, R. O., \& OguntibejuO.O. (2010). Job satisfaction among selected workers in St Lucia, West Indies. Scientific Research and Essays, 5(12), 1436-1441.

Ranjit, L. (2012). Study on influence of demographic factors on job satisfaction of textile mill workers. Zenith International Journal of Business Economics \& Management Research, 2, 14-29.

Tabatabaci, S., Ghaneh, S., Mohaddes, H., \& Khansani, M. (2013). Relationship of job satisfaction and demographic variables in Pars Ceram factory. Social and Behavioral Science, 84, $1795-1800$. Doi: 10:1016/j. sbspro.07.036. 